\title{
Sedimentary changes on the Southeastern Brazilian upper slope during the last 35,000 years
}

\author{
MICHEL M. MAHIQUES ${ }^{1}$, MARINA M. FUKUMOTO ${ }^{2}$, ILSON C.A. SILVEIRA ${ }^{1}$ \\ RUBENS C.L. FIGUEIRA ${ }^{3}$, MARCIA C. BÍCEGO ${ }^{1}$, RAFAEL A. LOURENÇO ${ }^{2}$ \\ and SILVIA H. MELLO-E-SOUSA ${ }^{1}$ \\ ${ }^{1}$ Instituto Oceanográfico da Universidade de São Paulo, Departamento de Oceanografia Física, Química e Geológica \\ Praça do Oceanográfico, 191, 05508-900 São Paulo, SP, Brasil \\ ${ }^{2}$ Programa de Pós-graduação em Oceanografia Química e Geológica, Instituto Oceanográfico da Universidade de São Paulo \\ Praça do Oceanográfico, 191, 05508-900 São Paulo, SP, Brasil \\ ${ }^{3}$ Universidade Cruzeiro do Sul, Av. Dr. Ussiel Cirilo, 225, 08060-070 São Paulo, SP, Brasil \\ Manuscript received on February 1, 2006; accepted for publication on April 24, 2006; \\ presented by MÁRCIO M. PIMENTEL
}

\begin{abstract}
A first evaluation of the sedimentary changes, including accumulation of inorganic and organic carbon on the upper slope off Southeastern Brazil under different climatic conditions, based on the analysis of a sedimentary core, is here presented. Results indicate that sedimentation rate as well sedimentary characteristics, including the nature of the organic carbon deposited during the LGM (Last Glacial Maximum), were different from the present deposition, indicating higher primary productivity during the LGM, to be accounted for by the higher values of marine organic carbon. Nevertheless, the higher values of Accumulation Rate of calcium carbonate and organic carbon can be credited to the higher values of the sedimentation rates. Conditions prevailing during Isotope Stage 3 may be considered intermediate as between the LGM and the present day. The conditions for a higher primary productivity associated with the deposition of finer terrigenous sediments may be explained as a response to the offshoreward displacement of the main flow of the Brazil Current.
\end{abstract}

Key words: sedimentation, accumulation rate, upper slope, Southeastern Brazil.

\section{INTRODUCTION}

Due to the lack of significant upwelling areas as well as to a relatively limited fluvial input the western South Atlantic tropical and subtropical margins have been much less intensively studied than its eastern counterparts (Cohen and Tyson 1995, Ternois et al. 2000, deMenocal et al. 2000, Sicre et al. 2001).

At the present time, the displacement of the warm waters of the Brazil Current leads to low levels of primary productivity, with consequent small amounts of sedimentary organic matter (Mahiques et al. 1999), exceptions being related to some few coastal upwelling areas and

Correspondence to: Michel Michaelovitch de Mahiques E-mail: mahiques@usp.br river mouths (Mahiques et al. 2005). However, almost nothing is known about the paleoproductivity of the eastern Brazilian margin under different paleoclimatic conditions.

As a function of its importance in $\mathrm{CO}_{2}$ dynamics the burial of organic and inorganic carbon in marine sediments and its variation under different climatic conditions is one of the main tasks of the modern marine sciences (Giraudeau et al. 2002, Mollenhauer et al. 2004). From this point of view, not only is the total amount of organic and inorganic carbon deposited important, but the estimates of accumulation rates and, in the case of organic carbon, its origin, are also key questions for the comprehension of the carbon cycle. 
According to Mollenhauer et al. (2004), during the LGM the accumulation of organic carbon in deep basins of the tropical and subtropical South Atlantic was two to three times greater than during the Holocene. On the other hand, those authors observe that the accumulation of organic carbon during the LGM was not related to a corresponding increase in the paleoproductivity but was, rather, related to changes in the chemistry of the South Atlantic water masses as well as to the exposure of the continental shelves and, consequently, to the direct input of terrigenous organic matter to deeper areas.

A first evaluation of the sedimentary changes, including accumulation of inorganic and organic carbon on the upper slope off Southeastern Brazil, under different climatic conditions and based on the analysis of a sedimentary core, is here provided.

\section{MORPHOLOGY AND OCEANOGRAPHY OF THE STUDY AREA}

The study area corresponds to the upper slope off Southeastern Brazil (Figure 1), in the morphologic sector of the Brazilian margin known as the São Paulo Bight. The São Paulo Bight is the arc-shaped part of the eastern Brazilian margin extending from $23^{\circ} \mathrm{S}$ to $28^{\circ} \mathrm{S}$ (Zembruscki 1979).

The ocean floor of the São Paulo Bight shows a rather complex morphology involving channels, canyons, and considerable variations in the slope morphology (Furtado et al. 1996). The shelf break is located at a depth of approximately 140 meters with the upper slope showing an average gradient of approximately 1:55. In the eastern sector off São Sebastião island, close to the 600-m isobath $\left(25^{\circ} \mathrm{S}, 44^{\circ} 30^{\prime} \mathrm{W}\right)$, the upper slope changes into a fan-shaped feature at the end of the Búzios Channel.

On the middle and outer shelves as well as on the upper slope, sedimentary processes are influenced by the flow of the BC (Brazil Current) along the western Atlantic continental margin (Mahiques et al. 2002, 2004). The $\mathrm{BC}$ transports Tropical Water $\left(\mathrm{TW}, \mathrm{T}=25.0^{\circ} \mathrm{C}\right.$, $\mathrm{S}=37.1)$ at upper levels and South Atlantic Central Water $\left(\mathrm{SACW}, \mathrm{T}=14.0^{\circ} \mathrm{C}, \mathrm{S}=35.5\right)$ at pycnocline levels (Miranda 1985, Silveira et al. 2001). The BC main flow is centered on the 1000 meter isobath (N. Garfield, unpublished data).

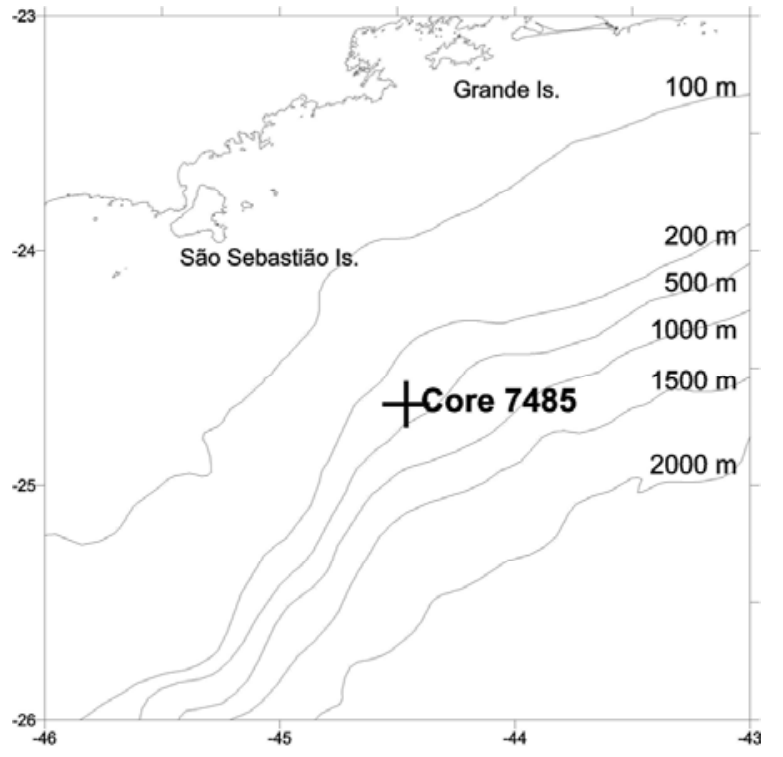

Fig. 1 - Location of the core studied in this project.

According to Campos et al. (2000), the BC develops a convoluted pattern of meanders in the vicinity of Cape Frio. The reason for this is the change in the lie of the Brazilian coastline, which contributes to the formation of a clockwise meander of the BC in the latter's attempt to conserve angular momentum. The consequence is a vortical structure with upwelling associated with its southernmost part and downwelling with its northernmost part. A counter-clockwise meander is often found downstream of the Cape Frio meander and a topographic Rossby wave pattern is observed inside the São Paulo Bight.

The inner and middle shelf dynamics are determined by the displacement of three water masses which present strong seasonal variation (Castro Filho et al. 1987). Due to the prevalence of east-northeasterly winds, between November and March the SACW (South Atlantic Central Water) moves close to the bottom toward the coast, leading to the oceanward displacement of the less dense CW (Coastal Water) and keeping the TW (Tropical Water) relatively distant from the coastline. Due to the advance of the cold waters of the SACW a seasonal upwelling phenomenon occurs. From April to October, the prevalence of southerly winds favors the advance of the TW towards the shelf and the consequent retreat of the SACW. 
The distribution of surface sediments on the Southeastern Brazilian margin was extensively studied during the 70's and is described in the papers of Rocha et al. (1975) and Kowsmann and Costa (1979). In general, the present sea-loor is covered by very fine siliciclastic sands and silts, with variable amounts of clay and calcium carbonate. Coarser sediments and carbonate gravel and boulder facies, found on the outer shelf, represent less than $5 \%$ of the present bottom sediments and are generally related to relict sediments, deposited under lower sea-level conditions. More recently, Mahiques et al. $(2002,2004)$ have re-evaluated the sedimentary characteristics of the Southeastern Brazilian shelf and proposed hydrodynamic models for the sediment deposition in the area.

\section{MATERIALS AND METHODS}

A 203-cm long sediment core was collected during a 2003 cruise on board the R.V. "Prof. W. Besnard". Geographical coordinates were $24^{\circ} 39.27^{\prime} \mathrm{S}$ and $044^{\circ} 27.74^{\prime} \mathrm{W}$ and water depth is 374 meters (Figure 1). Magnetic susceptibility measurements were performed on board using a Bartington MS2C sensor.

After the core had been opened it was described and sampled continuously at $2 \mathrm{~cm}$ intervals. Sediment samples were frozen for later freeze-drying.

The age model for core 7485 was based on ten accelerator mass spectrometry (AMS) radiocarbon datings of foraminifera tests, as presented in Table I. All datings were performed at Beta Analytic Inc. (USA). The SW Atlantic Reservoir correction $(\Delta R=87, U=46)$ was applied to the samples. Grain size was determined from decarbonated samples in a Malvern Mastersizer 2000 analyzer. Calcium carbonate content was determined via weight difference prior to and after the acidification of $1 \mathrm{~g}$ of the sample with a $10 \%$ hydrochloric acid solution (Gross 1971). A comparison of this method with inorganic carbon determination in a LECO CNS2000 analyzer was performed for $10 \%$ of the samples and the results proved compatible.

Organic carbon and total nitrogen were determined in a LECO CNS2000 analyzer. Approximately 200 mg of dry sediment of each sample was treated with $1 \mathrm{~N} \mathrm{HCl}$ in order to remove calcium carbonate and then freezedried and analyzed. LECO soil standards and blanks
TABLE I

Radiocarbon ages of core 7485 .

\begin{tabular}{c|c|c}
\hline Depth $(\mathrm{cm})$ & BETA Number & $\begin{array}{c}\text { Conventional } \\
\text { Radiocarbon } \\
\text { Age (yr B.P.) }\end{array}$ \\
\hline 1 & 189509 & $3020 \pm 40$ \\
11 & 189510 & $7420 \pm 40$ \\
21 & 189511 & $14230 \pm 90$ \\
31 & 185176 & $17240 \pm 90$ \\
51 & 185177 & $18070 \pm 160$ \\
77 & 185178 & $18560 \pm 140$ \\
127 & 185179 & $19700 \pm 250$ \\
151 & 185180 & $21750 \pm 160$ \\
171 & 185181 & $24860 \pm 270$ \\
201 & 185182 & $34800 \pm 400$ \\
\hline
\end{tabular}

were analyzed as controls for each set of 30 samples.

Values of $\delta^{13} \mathrm{C}_{\mathrm{PDB}}$ of the sedimentary organic content were obtained by mass spectrometry at the Coastal Science Laboratories (Austin, TX, USA). Carbon isotope analyses were performed by online combustion with a Fisons NA1500 Elemental Analyzer attached to a VG SIRA Model 10 mass spectrometer. Carbon isotope was calibrated using the NBS 22 oil standard (defined as $-29.60 \%$ relative to PDB). Reproducibility for carbon isotope was better than $0.2 \%$.

Mass accumulation rates of calcium carbonate $\left(\mathrm{CaCO}_{3} \mathrm{MAR}\right)$ and organic carbon ( $\left.{ }_{\text {org }} \mathrm{C} \mathrm{MAR}\right)$, in g. $\mathrm{cm}^{-2} \cdot \mathrm{kyr}^{-1}$, were calculated in accordance with the formula described in Grant and Dickens (2002):

$$
\begin{gathered}
\mathrm{CaCO}_{3} \mathrm{MAR}\left(\text { or }_{\text {org }} \mathrm{C} \mathrm{MAR}\right)= \\
\left(\% \mathrm{CaCO}_{3}(\text { or } \% \text { org })\right) / 100 * \mathrm{SR}^{*} \mathrm{DBD}^{*} 1000
\end{gathered}
$$

where SR is the sedimentation rate $\left(\mathrm{cm} \cdot \mathrm{yr}^{-1}\right)$ obtained from the age model and DBD is the dry bulk density $\left(\mathrm{g} . \mathrm{cm}^{-3}\right)$, calculated from:

$$
\mathrm{DBD}=(1-\phi / 100) * \rho_{\mathrm{s}}
$$

where $\phi$ is the wet porosity and $\rho_{\mathrm{s}}$ is the density of the sediment particles, previously determined as $2.35 \mathrm{~g} . \mathrm{cm}^{-3}$.

The wet porosity $(\phi)$ was calculated using the formula proposed by Clifton et al. (1995):

$$
\phi=\frac{\left((\mathrm{W} / 100) * \rho_{\mathrm{s}}\right)}{\left(\left((\mathrm{W} / 100) * \rho_{\mathrm{s}}\right)+(1-(\mathrm{W} / 100)) * \rho_{\mathrm{W}}\right)}
$$


where $\mathrm{W}$ is the water content (in $\%$ ), $\rho_{\mathrm{s}}$ the density of the sediment particles, i.e. $2.35 \mathrm{~g} . \mathrm{cm}^{-3}$, and $\rho_{\mathrm{w}}$ the density of the pore water, assumed to be 1.0 g.cm ${ }^{-3}$.

\section{RESULTS AND DISCUSSION}

Results are presented in Figures 2 to 6.

Core Description, Age-Model and Sedimentation RATES (FIGURE 2)

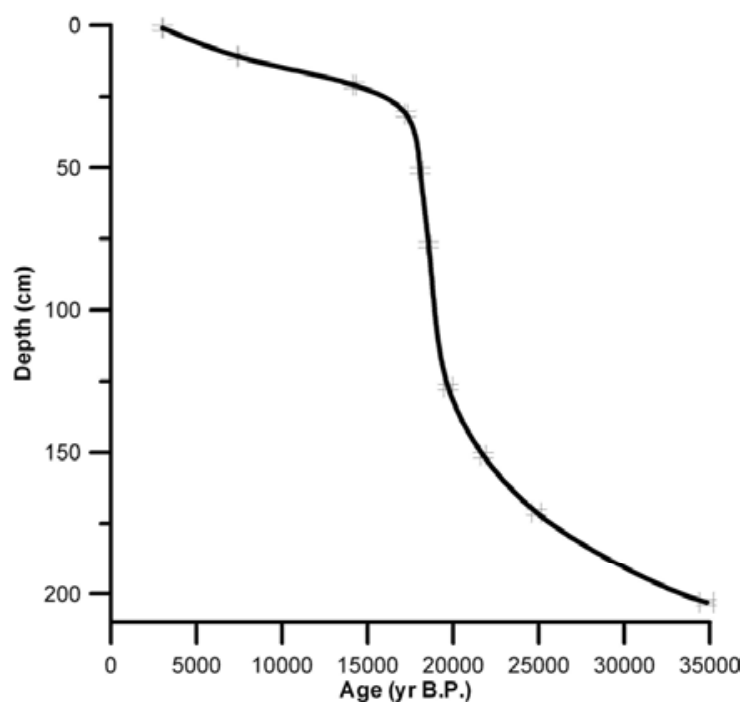

Fig. 2 - Age model for core 7485 .

The whole core is composed of massive greenishgray silty sediments, with a greater sandy contribution in the bottommost $40 \mathrm{~cm}$ as well as in the topmost $15 \mathrm{~cm}$. Bioclasts are dispersed within the matrix and no other sedimentary structure can be observed along the core.

The establishment of a reliable model for depthage relationships is a key question for all of the studies involving sediment accumulation and has been recently criticized by Telford et al. (2004). A basic assumption determined by these authors is that age-depth models are only meaningful and useful when established using calibrated radiocarbon ages. Nevertheless, due to the time span limitation of radiocarbon calibration this assumption is frequently not taken into consideration and agedepth models are used for much longer time intervals.

In order to evaluate the effect of the age-depth models on the values of sedimentation rates and, consequently, sediment accumulation, we tested several in- terpolation procedures (polynomial, linear interpolation between radiocarbon values, cubic spline and mixed effect). Polynomial, linear interpolation and cubic spline models were calculated using the DepthAge software, developed by Louis Maher Jr. and available at the INQUA file boutique at http://www.geology.wisc.edu/ $\sim$ maher/ inqua.html (last accessed December 15, 2006). The mixed-effect model was calculated by means of the Cagedepth and Cagenew functions as described by Heegard et al. (2005) and available at http://www.uib.no/ bot/qeprg/Age-depth.htm (last accessed December 15, 2005).

One particularity of the data here presented is the apparently extreme change in sedimentation rates as between LGM and Holocene, as shown by the radiocarbon data. This characteristic leads to the obtention of negative sedimentation rate values when using most of the polynomial approaches, despite their high statistical significance. This problem was also observed when the mixed-effect model was used. In this sense, the only age-depth models which could be assumed to be reliable were the cubic spline and linear interpolation between radiocarbon values. As stated by Grant and Dickens (2002), the linear interpolation leads to artificial sedimentation rate values and, consequently, the cubic spline approach was adopted as the age-depth model and used for the calculation of sedimentation rates and accumulation values.

The core covers an age range of 34,800 years. There was not any age inversion in the radiocarbon datings. Holocene sediments correspond only to the first $19 \mathrm{~cm}$ of the sedimentary column, revealing a sedimentation rate ranging from 0.0014 to $0.0026 \mathrm{~cm} . \mathrm{yr}^{-1}$ for the period.

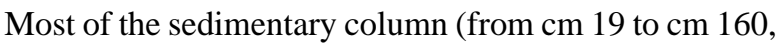
approximately) consists of Isotope Stage 2 sediments and higher sedimentation rates are found in this period, between 18,800 to 18,700 years B.P. During Isotope Stage 3 , sedimentation rates remained approximately constant (between 0.0300 and $0.0500 \mathrm{~cm} \cdot \mathrm{yr}^{-1}$ ).

The changes in sedimentation rates observed in this study seem to be too dramatic for such a short time period. Nevertheless, this has been already verified in other shelf and upper slope areas. Knies (2005) observed changes in sedimentation rates by a factor of 12 as between the Holocene and older layers in shelf sediments 


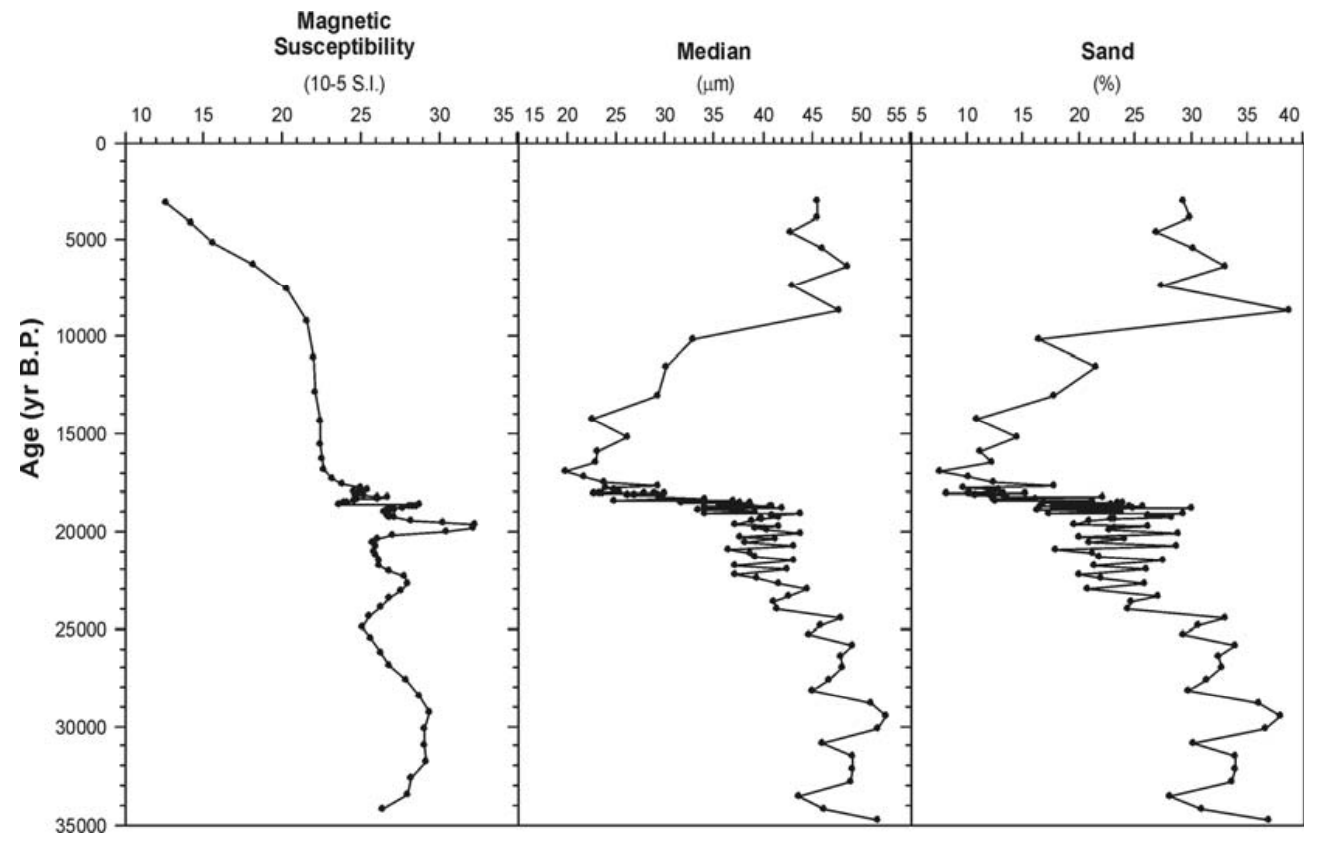

Fig. 3 - Variations in magnetic susceptibility and grain-size in core 7485. Isotope stage limits based on Martinson et al. (1987).

off northern Norway. The same behavior was observed for an equivalent period on the shelf off NE Iceland (Andresen et al. 2005).

\section{MAgnetic Susceptibility AND GRAin-Size (FIgURE 3)}

There is a conspicuous change in magnetic susceptibility as between Isotope Stage 2 and the younger sediments in the core. Values higher than $23.10^{-5}$ S.I. are found only in sediments older than 18,000 years B.P., revealing a considerable change in inorganic terrigenous input to the study area. From the LGM to the present time there is a gradual decrease in magnetic susceptibility values. Isotope 3 sediments show susceptibility values of the same magnitude as those of Stage 2. Magnetic susceptibility values indicate that, in comparison with the Holocene sediments, the samples from stages 3 and 2 present values that may be considered relatively high, suggesting that the input of terrigenous sediments during these periods remained approximately constant.

The grain size, revealed by the graphs of time versus median size (in $\mu \mathrm{m}$ ) and sand content (\%) shows a considerable fining upward, from Stage 3 sediments $(50 \mu \mathrm{m}$, $35 \%$ of sand) towards the LGM $(20 \mu \mathrm{m}$, less than $15 \%$ of sand). There is a coarsening trend from this age towards the top of the core $(45 \mu \mathrm{m}$, more than $25 \%$ of sand).

An integrated analysis of magnetic susceptibility and grain-size indicates that, together with a more efficient terrigenous input, probably as a consequence of the narrowing of the shelf during Isotope Stages 3 and 2 , there is a clear change in hydrodynamic conditions when the shelf is totally or partially flooded (Isotope Stage 3 and Holocene). The prevalence of finer sediments during the LGM suggests a weakening and/or an offshoreward displacement of the main upper-slope hydrodynamic agent, i.e. the Brazil Current, leading to a diminishing capacity of sediment remobilization during the period. Prior to ca. 30,000 years B.P. the hydrodynamic conditions were more energetic than those of the Holocene.

\section{Calcium Carbonate Content and Carbonate Mass ACCUMUlation Rate (Figure 4)}

The variations of calcium carbonate content are also indicative of a terrigenous dilution of the carbonatic sedimentation during the LGM. Values of Stage 3 oscillate around $25 \%$ while sediments from the LGM show val- 


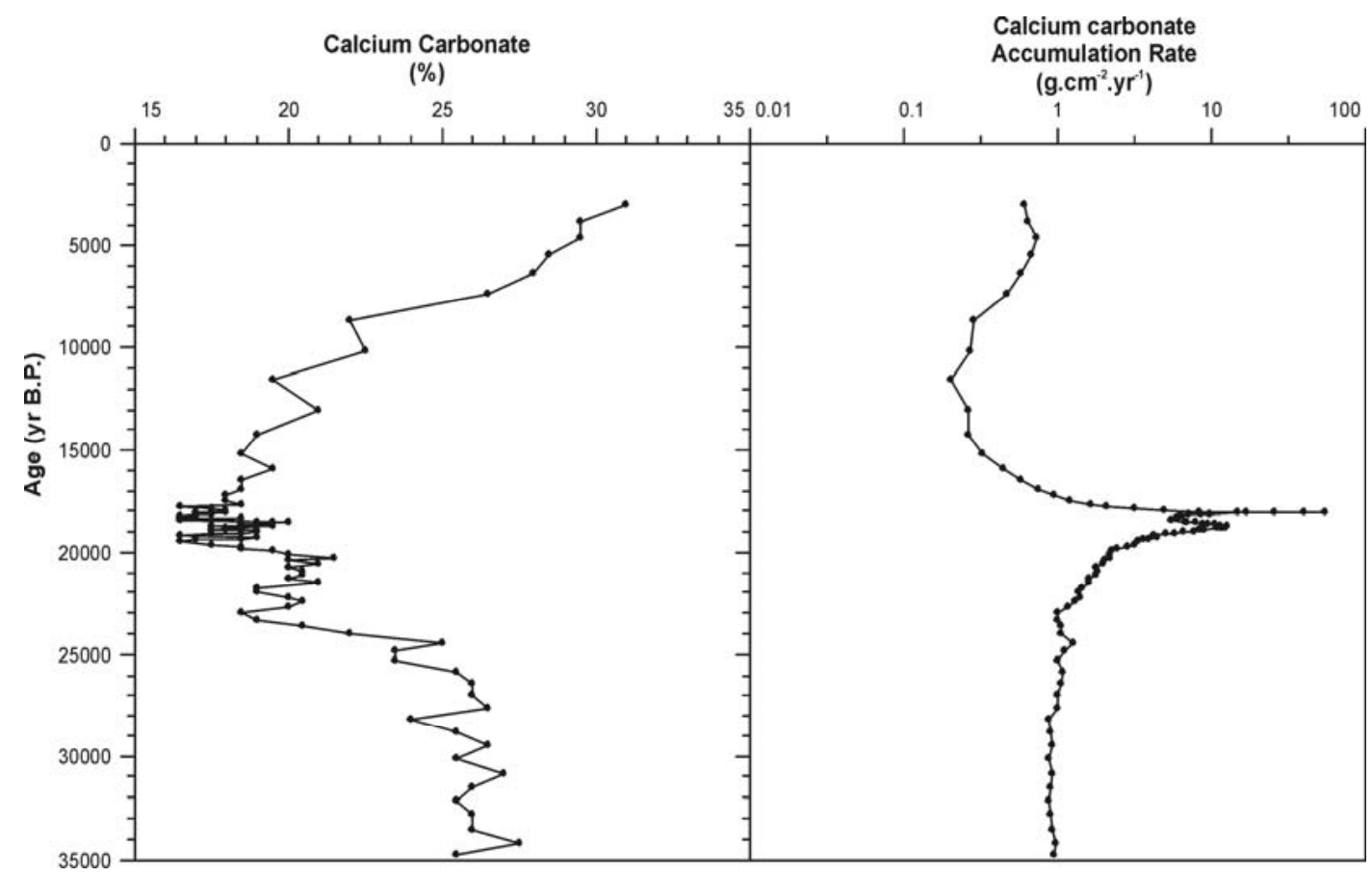

Fig. 4 - Variations in calcium carbonate content and carbonate Mass Accumulation Rate in core 7485. Isotope stage limits based on Martinson et al. (1987).

ues as low as $16 \%$. There is a continuous increase in carbonate content from 15,000 years towards the top of the core where values are of around $30 \%$.

On the other hand the Carbonate Mass Accumulation Rate $\left(\mathrm{CaCO}_{3}\right.$ MAR) has been greatly influenced by the significant changes in sedimentation rates along the core. Values which represent two orders of magnitude higher than those of the Holocene samples are found around 18,000 to 19,000 years B.P., smaller variations having been virtually obliterated. While Isotope Stage 3 sediments show accumulation rates of less than $1.0 \mathrm{~g} . \mathrm{cm}^{-2} \cdot \mathrm{kyr}^{-1}$ and those of the post-Last Glacial Maximum exhibit values smaller than $0.8 \mathrm{~g} . \mathrm{cm}^{-2} \cdot \mathrm{kyr}^{-1}$, the Isotope Stage 2 sediments show values as high as $55 \mathrm{~g} . \mathrm{cm}^{-2} \cdot \mathrm{kyr}^{-1}$, which can be clearly assumed to be an overestimate, especially considering the percentages of calcium carbonate and its dilution due to the higher terrigenous input during the LGM.

Temporal variations in carbonate accumulation rates, associated with changes in sedimentation rates, have been established by Agnihotri et al. (2003) for the Arabian Sea.
Organic CARbon, Total Nitrogen, C/N RATIO AND $\delta^{13} \mathrm{C}_{\mathrm{PDB}}$ (Figure 5)

There is a slight increase in the organic matter content in the LGM samples, as revealed by the organic carbon and total nitrogen values. In general, samples from Stage 3 and the Holocene show organic carbon lower than $0.3 \%$ and total nitrogen lower than $0.05 \%$; samples from the LGM showing values higher than $0.4 \%$ and $0.05 \%$, respectively for carbon and nitrogen. There is an unexpected continuous increase in $\mathrm{C} / \mathrm{N}$ ratio values towards the base of the core. Since the organic character of the nitrogen may be guaranteed by the high correlation between organic carbon and total nitrogen $(\mathrm{R}=0.90)$, it seems that the higher $\mathrm{C} / \mathrm{N}$ ratio values at the base of the core are much more closely related to the low nitrogen values than to a post-depositional effect.

The $\mathrm{C} / \mathrm{N}$ ratio trend is also contradicted by the behavior of $\delta^{13} \mathrm{C}_{\mathrm{PDB}}$ values along the core. Higher $\delta^{13} \mathrm{C}_{\mathrm{PDB}}$ values (around $-20.4 \%$ ) are present along the Isotope Stage 3 up to circa 23,000 years B.P., when they show a slight change to values close to $-21.0 \%$. The 


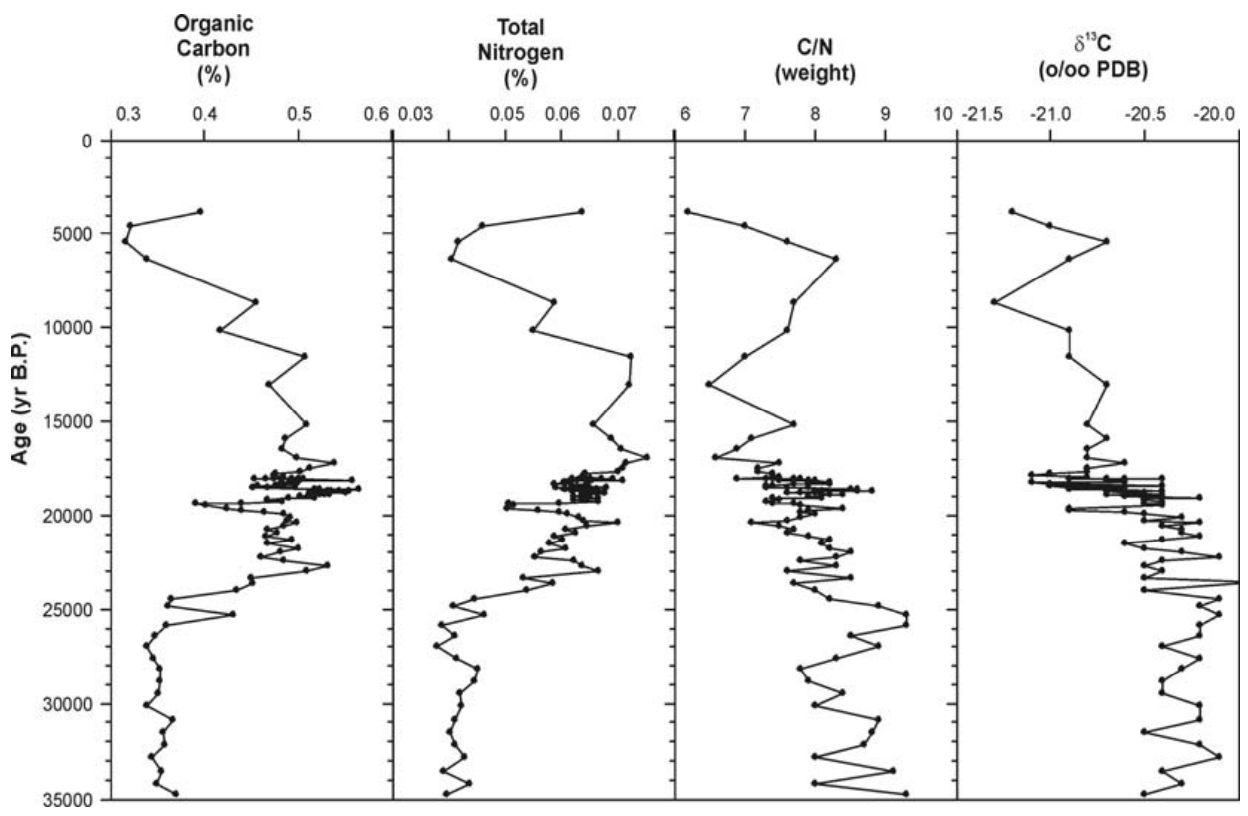

Fig. 5 - Variations in organic carbon, total nitrogen, $\mathrm{C} / \mathrm{N}$ ratio and $\delta^{13} \mathrm{C}$ in core 7485 . Isotope stage limits based on Martinson et al. (1987).

post-LGM sediments maintain their tendency to lighter isotope values. The apparent contradiction between $\delta^{13} \mathrm{C}_{\mathrm{PDB}}$ and $\mathrm{C} / \mathrm{N}$ values may be related to partial degradation of algal organic matter, leading to the decrease in the proteinaceous components and, hence, to that of the $\mathrm{C} / \mathrm{N}$ ratio, also (Meyers 1997).

Marine and Terrestrial Organic CARbon Content AND ACCUMUlation RATES (FIgURE 6)

According to McKay et al. (2004) it is necessary to estimate the relative abundance of marine and terrestrial organic matter when using organic carbon as a proxy for paleoproductivity. In our study this estimate has been made by using the following equation:

Terrigenous fraction $=\frac{\left(\delta^{13} \mathrm{C}_{\text {PDBsample }}-\delta^{13} \mathrm{C}_{\mathrm{PDB} m a r}\right)}{\left(\delta^{13} \mathrm{C}_{\mathrm{PDB} \text { terr }}-\delta^{13} \mathrm{C}_{\mathrm{PDBmar}}\right)}$

where $\delta^{13} \mathrm{C}_{\mathrm{PDB} m a r}$ and $\delta^{13} \mathrm{C}_{\mathrm{PDB} \text { err }}$ correspond to the marine and terrestrial end-members, respectively. This same procedure has been used successfully by Minoura et al. (1997), Fernandes and Sicre (2000) and McKay et al. (2004).

Mahiques et al. (1999) used the $\delta^{13} \mathrm{C}_{\mathrm{PDB}}$ values of $-19.0 \%$ and $-26.0 \%$ for marine and terrestrial end-members, respectively, on the Southeastern Brazilian shelf. Matsuura and Wada (1995) reported $\delta^{13} \mathrm{C}_{\mathrm{PDB}}$ values ranging from $-20.5 \%$ to $-21.1 \%$ for plankton and $-26.1 \%$ for tree leaves from the coast off Ubatuba (SE Brazil); nevertheless care must be taken since these plankton $\delta^{13} \mathrm{C}_{\mathrm{PDB}}$ values represent not only phytobut, also, microzooplankton. In the Cananéia estuarine system (SE Brazil), Barcellos et al. (2005) determined average $\delta{ }^{13} \mathrm{C}_{\mathrm{PDB}}$ values of $-25.6 \%$ for mangrove trees and $-19.4 \%$ for phytoplankton.

Due to the relatively small importance of the mangrove vegetation, in comparison with other tropical and subtropical rainforests of the Southeastern Brazilian coast, it may be assumed that the $\delta^{13} \mathrm{C}_{\mathrm{PDB}}$ values of $-26.0 \%$ and $-19.0 \%$ can be used as reliable endmembers for the determination of the amounts of terrestrial and marine organic matter, respectively. The amounts of marine and terrestrial organic carbon as well as their accumulation rates have been calculated on the basis of this assumption. Higher values of marine organic carbon ( $>0.4 \%$ org $\mathrm{C}_{\text {marine }}$ ) are found between 24,000 and 18,000 years B.P.

The accumulation rates of total, marine and terrigenous organic carbon present the same trend observed 


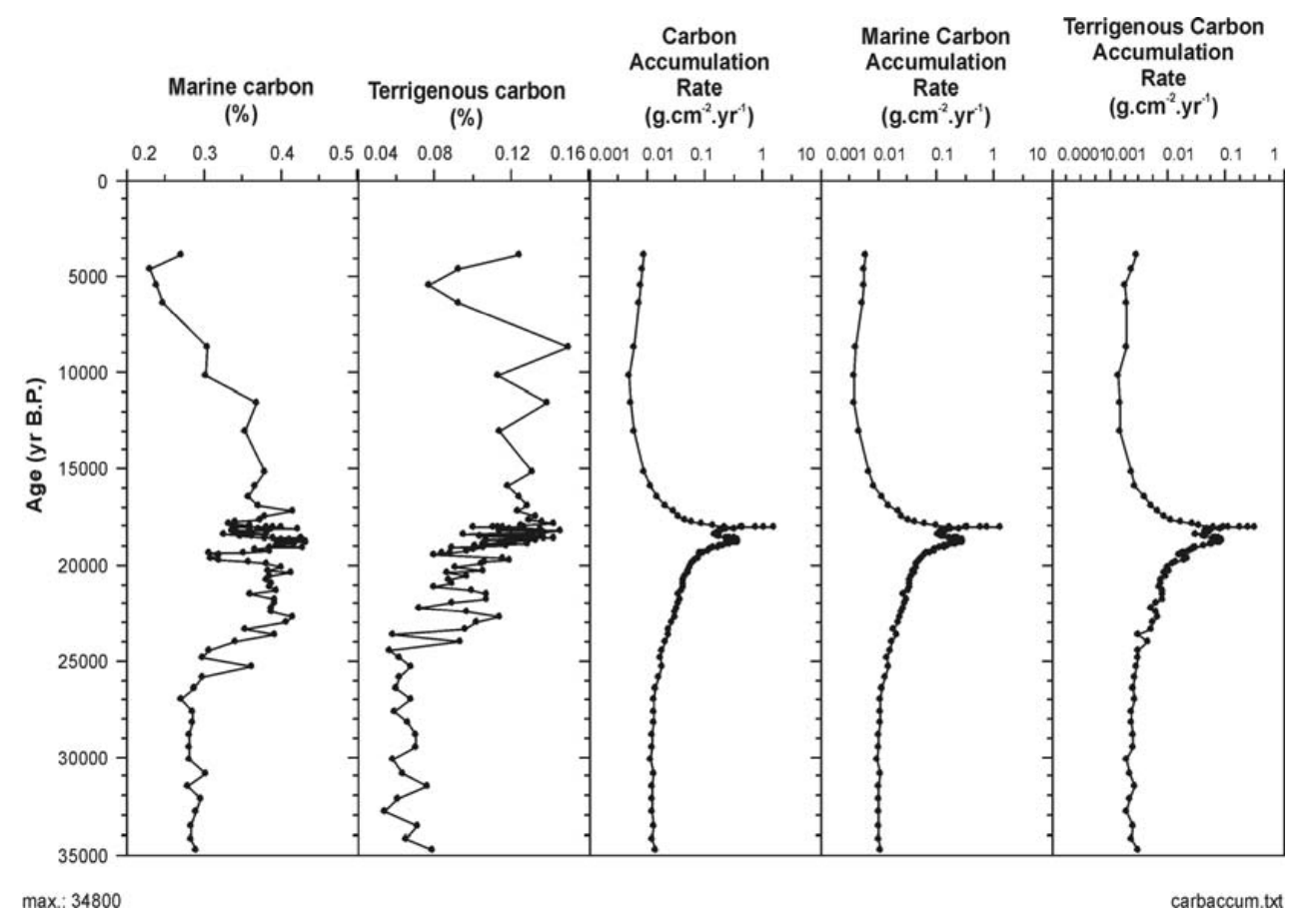

Fig. 6 - Variations in marine and terrestrial organic carbon content and accumulation rates in core 7485 . Isotope stage limits based on Martinson et al. (1987).

in the calcium carbonate accumulation rate. Total organic carbon exhibits values ranging from 0.005 to $1.580 \mathrm{gC} . \mathrm{cm}^{-2} \cdot \mathrm{ky}^{-1}$, higher values being found between 19,000 and 18,000 years B.P. Analogous behavior is to be observed in the marine and terrigenous organic carbon accumulation rates. In all of these parameters, the values for Isotope Stage 3 and the Holocene remain approximately constant, that for the latter being slightly smaller.

Very high differences in carbon accumulation rates under different paleoclimatic conditions have been observed in several areas. Agnihotri et al. (2003) identified a decoupling of carbon accumulation from productivity; according to those authors, changes in sedimentation rates might be responsible for the better preservation of carbon during the LGM. Schlunz et al. (2000) also found a relationship between Total Organic Carbon Accumulation Rates and Sedimentation Rate and the eustatic curve, in the Barbados area. In the Arabian Sea, the organic carbon accumulation rate does not show any relationship with other paleoproductivity proxies (Pattan et al. 2003).
The changes in the sedimentary characteristics, as well as the occurrence of changes in inorganic and organic carbon deposition and accumulation rates on the Southeastern Brazilian shelf during the LGM, may be explained by a simple conceptual model involving changes in shelf width as well as the position of the Brazil Current under different climatic conditions (Figure 7). During the periods of higher sea-level, corresponding to Isotope Stage 3 and the Holocene, the displacement of the warm waters of the Brazil Current towards the coast prevents the increase in water productivity. Further, the scouring action of the Brazil Current on the sea-bed, as demonstrated by the bigger grain size values, prevents the deposition of mud and, consequently, of organic matter. Very low sedimentation rates are a consequence of a "floor-polisher" effect on the sea-bottom, described by Mahiques et al. (2004) for the study area.

During periods of lower sea-level, together with the narrowing of the shelf, the Brazil Current is displaced offshorewards, permitting the input of nutrients, as expressed by the higher values of nitrogen, and ter- 


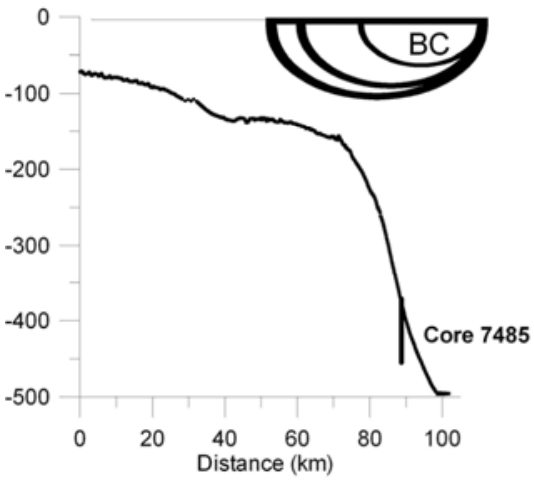

(A)

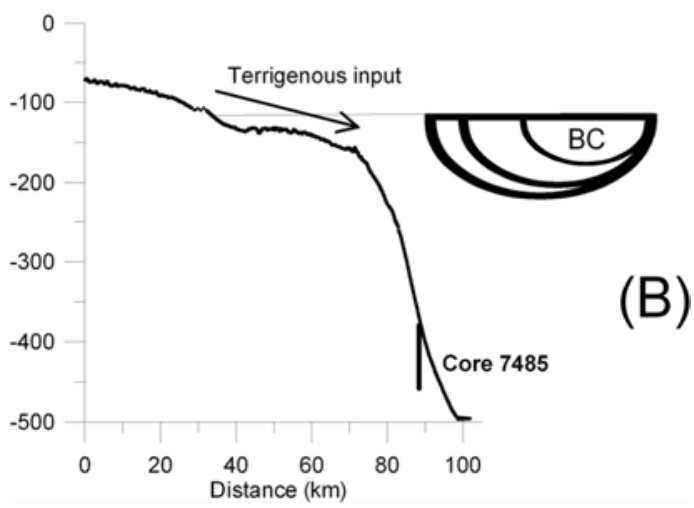

Fig. 7 - Schematic model for the position of the Brazil Current (BC) under different climatic conditions (a) Present and Isotope Stage 3 and (b) Last Glacial Maximum.

rigenous materials. Finer sediments are deposited as a consequence of changes in the competence of the main upper slope hydrodynamic agent.

The offshoreward displacement of the Brazil Current has also been reported by Viana et al. (1998) for the Campos continental margin, northward of this present study area. Nevertheless, in the Campos area this displacement was used to explain a trend of more highly energetic conditions on the upper slope during glacial lowstand stages. In fact, this might be acceptable for the areas which are presently within the transitional zone between the southward flow of the BC (Brazil Current), which transports the TW (Tropical Water) and the SACW (South Atlantic Central Water), and the northward flow of the IWBC (Intermediate Western Boundary Current), transporting AAIW Antarctic Intermediate Water) (Silveira et al. 2004). In this area, the inversion of flow is responsible for the low current speeds at depths between 400 and 500 meters.

\section{CONCLUSIONS}

The analysis of sedimentological constituents in a sediment core spanning a time interval of approximately 35,000 years indicates the occurrence of significant changes in the sedimentation on the upper slope off Southeastern Brazil. Besides the changes in the amount of organic carbon deposited it has been established that during the LGM there was an increase in the marine productivity of the area, as revealed by the occurrence of higher levels of marine organic carbon.

Care must be taken with the extremely high values found for the accumulation rates of calcium carbonate and organic carbon during the LGM since they may have been influenced by the higher values of the sedimentation rates in that period.

A conceptual model, in which the offshoreward displacement of the main flow of the BC during periods of lower sea level, may be used to explain the differences between this period and Isotope Stage 3 and the Holocene. During the periods of higher sea-level the displacement of the warm waters of the $\mathrm{BC}$ towards the coast prevented any increase in water productivity as also of the deposition of organic matter. During periods of lower sea-level, the input of nutrients as well as of terrigenous materials favored the productivity and deposition of organic carbon.

\section{ACKNOWLEDGMENTS}

The authors are indebted to the crew of the R.V. "Prof. W. Besnard" and to the researchers who joined the "Buzios project" cruise in September 2003. Financial support was provided by Fundação de Amparo à Pesquisa do Estado de São Paulo (FAPESP), by grants 01/13490-9 and $03 / 10740-0$.

\section{RESUMO}

Este trabalho apresenta uma primeira avaliação das mudanças sedimentares, incluindo a acumulação de carbono orgânico e inorgânico, no talude continental superior do Brasil, sob diferentes condições climáticas, baseadas em análises de um testemunho. Os resultados indicam que a taxa de sedimentação, assim como as características sedimentares, incluindo a natureza do carbono orgânico depositado durante o UMG (Ú1timo Máximo Glacial), foram diferentes dos processos deposi- 
cionais atuais, indicando maior produtividade primária durante o UMG, como determinado pelos maiores valores de carbono orgânico marinho. Entretanto, os maiores valores de Taxa de Acumulação de carbonato de cálcio e carbono orgânico podem ser creditados aos valores mais altos de taxas de sedimentação. As condições prevalentes durante o Estágio Isotópico 3 podem ser consideradas intermediárias entre o UMG e as condições atuais. As condições para maior produtividade primária, associada à deposição de sedimentos mais finos, podem ser explicadas como uma resposta ao deslocamento, em direção ao mar aberto, do fluxo principal da Corrente do Brasil.

Palavras-chave: sedimentação, taxa de acumulação, talude superior, Sudeste do Brasil.

\section{REFERENCES}

Agnihotri RA, SARin MM, Somayajulu BLK, Jull AJT AND BURR GS. 2003. Late-Quaternary biogenic productivity and organic carbon deposition in the eastern Arabian Sea. Palaeogeogr Palaeoclimatol Palaeoecol 197: 43-60.

Andresen CS, Bond G, KuiJpers A, Knutz PC And BJÖRN S. 2005. Holocene climate variability at multidecadal time scales detected by sedimentological indicators in a shelf core NW off Iceland. Mar Geol 214: 323-338.

BARcellos RL, CAMARgo PB, BRIZZOTTI M AND FuRTADO VV. 2005. Seasonal stable carbon isotope $\left(\delta^{13} \mathrm{C}\right)$ variations in sediments of the Cananéia-Iguape lagoonal estuarine system, São Paulo State, Southeastern Brazil. In: $10^{\text {th }}$ INTERNATIONAL S YMPOSIUM ON "THE INTERACTIONS BETWEEN SEDIMENTS AND WATER". Abstracts. RMZ - Materials and Geoenvironment 52: 188.

Campos EJD, Velhote D and Silveira ICA. 2000. Shelf break upwelling driven by Brazil Current cyclonic meanders. Geophys Res Letts 27: 751-754.

Castro Filho BM, Miranda LB and Miyao SY. 1987. Condições hidrográficas na plataforma continental ao largo de Ubatuba: variações sazonais e em média escala. B Inst Ocean São Paulo, SP, Brasil 35: 135-151.

Clifton RJ, Watson PG, Davey JT ANd Frickers PE. 1995. A study of processes affecting the uptake of contaminants by intertidal sediments, using the radioactive tracers: ${ }^{7} \mathrm{Be},{ }^{137} \mathrm{Cs}$ and unsupported ${ }^{210} \mathrm{~Pb}$. Estuar coast Shelf Sci 41: 459-474.

CoHen AL AND Tyson PD. 1995. Sea-surface temperaturefluctuations during the Holocene off the south coast of
Africa - Implications for terrestrial climate and rainfall. Holocene 5: 304-312.

DeMenocal P, Ortiz J, Guilderson T and SARnTHEIN M. 2000. Coherent high- and low-latitude climate variability during the Holocene warm period. Science 288: 2198-2202.

FERnANDES MB AND SiCRE MA. 2000. The importance of terrestrial organic carbon inputs on Kara Sea shelves as revealed by n-alkanes, $\mathrm{OC}$ and $\delta^{13} \mathrm{C}$ values. Org Geochem 31: $363-374$.

Furtado VV, Bonetti Filho J and Conti LA. 1996. Paleo river morphology and sea level changes at southeastern Brazilian continental shelf. An Acad Bras Cienc 68: $163-169$.

Giraudeau J, Meyers PA And Christensen BA. 2002. Accumulation of organic and inorganic carbon in PliocenePleistocene sediments along the SW African margin. Mar Geol 180: 49-69.

GRANT KM AND DiCKENS GR. 2002. Coupled productivity and carbon isotope records in the southwest Pacific Ocean during the late Miocene - early Pliocene biogenic bloom. Palaeogeogr Palaeoclimatol Palaeoecol 187: 61-82.

Gross MG. 1971. Carbon determination. In: CARVER RE (Ed), Procedures in Sedimentary Petrology, New York: Wiley-Interscience, p. 573-596.

HeEgard E, Birks HJB AND Telford RJ. 2005. Relationships between calibrated ages and depth in stratigraphical sequences: an estimation procedure by mixed-effect regression. Holocene 15: 612-618.

KNIES J. 2005. Climate-induced changes in sedimentary regimes for organic matter supply on the continental shelf off northern Norway. Geochim Cosmochim Acta 69: 46314647.

Kowsmann RO And Costa MOA. 1979. Sedimentação quaternária da margem continental brasileira e das áreas oceânicas adjacentes (relatório final). In: PROJETO REMAC. Petrobras, Rio de Janeiro, RJ, Brasil, p. 1-55.

Mahiques MM, Mishima Y AND Rodrigues M. 1999. Characteristics of the sedimentary organic matter on the inner and middle continental shelf between Guanabara Bay and São Francisco do Sul, eastern Brazilian margin. Continent Shelf Res 19: 775-798.

MaHiques MM, Silveira ICA, Sousa SHM AND RoDRIGUES M. 2002. Post-LGM sedimentation on the outer shelf / upper slope of the northernmost part of the São Paulo Bight, eastern Brazil. Mar Geol 181: 387-400.

Mahiques MM, Tessler MG, Ciotti AM, Silveira ICA, SOUSA SHM, FIGUEIRA RCL, TASSINARI CCG, 
FURTAdo VV AND PASSOS RF. 2004. Hydrodynamically-driven patterns of recent sedimentation in the shelf and upper slope off southeast Brazil. Continent Shelf Res 24: $1685-1697$.

Mahiques MM, Bícego MC, Silveira ICA, Sousa SHM, LOURENÇO RA AND FUKUMOTO MM. 2005. Modern sedimentation in the Cabo Frio upwelling system, Southeastern Brazilian shelf. An Acad Bras Cienc 77: 535-548.

Martinson DG, Pisias NG, HAYS JD, IMbrie J, Moore-Jr TC And Shackleton NJ. 1987. Age dating and the orbital theory of the Ice Ages: Development of a high-resolution 0 to 300,000-year chronostratigraphy. Quatern Res 27: 1-29.

MatsuURA Y AND WADA E. 1995. Carbon and nitrogen stable isotope ratios in marine organic matters of the coastal ecosystem in Ubatuba, southern Brazil. Cienc Cult 46: 141-146.

McKay JL, Pedersen TF and Kienast SS. 2004. Organic carbon accumulation over the last 16kyr off Vancouver Island, Canada: evidence for increased marine productivity during the deglacial. Quatern Sci Revs 23: 261-281.

Meyers PA. 1997. Organic geochemical proxies of paleoceanographic, paleolimnologic and paleoclimatic processes. Org Geochem 27: 213-250.

Minoura K, Hoshino K, NaKamura T and Wada E. 1997. Late Pleistocene-Holocene paleoproductivity circulation in the Japan Sea: sea-level control on $\delta^{13} \mathrm{C}$ and $\delta^{15} \mathrm{~N}$ records of sediment organic material. Palaeogeogr Palaeoclimatol Palaeoecol 135: 41-50.

MiRANDA LB. 1985. Forma de correlação T-S de massa de água das regiões costeira e oceânica entre o Cabo de São Tomé (RJ) e a Ilha de São Sebastião (SP), Brasil Bolm Inst Oceanogr S Paulo 33: 105-119.

Mollenhauer G, Schneider RR, JenNerJahn T, MÜLLER PJ AND WeFER G. 2004. Organic carbon accumulation in the South Atlantic Ocean: its modern, mid-Holocene and last glacial distribution. Glob Planet Change 40: 249-266.
Pattan JN, Masuzawa T, NAidu D, Parthiban G AND YAмAмото PM. 2003. Productivity fluctuations in the southeastern Arabian Sea during the last 140 ka. Palaeogeogr Palaeoclimatol Palaeoecol 193: 575-590.

Rocha J, Milliman JD, Santana CI And Vicalvi MA. 1975. Continental margin sedimentation off Brazil. Part 5: Southern Brazil. Contr Sedimentol 4: 117-150.

SCHLunz B, Schneider RR, Muller PJ AND WefER G. 2000. Late Quaternary organic carbon accumulation south of Barbados: influence of the Orinoco and Amazon rivers? Deep-Sea Res I 47: 1101-1124.

Sicre MA, Ternois Y, Paterne M, Martinez P And Bertrand P. 2001. Climatic changes in the upwelling region off Cap Blanc, NW Africa, over the last 70 kyear: a multi-biomarker approach. Org Geochem 32: 981-990.

SilveIRA ICA, SCHMidT ACJ, CAmpos EJD, Godoi SS AND IKEDA Y. 2001. A Corrente do Brasil ao Largo do Sudeste Brasileiro. Rev Bras Oceanogr 48: 171-183.

Silveira ICA, Calado L, Castro BM, Cirano M, LiMA JAM AND MASCARENHAS AS. 2004. On the baroclinic structure of the Brazil Current - Intermediate Western Boundary Current system at $22^{\circ}-23^{\circ} \mathrm{S}$. Geophys Res Lett 31: LI4308.

Telford RJ, Heegard E ANd Birks HJB. 2004. All agedepth models are wrong: but how badly? Quat Sci Rev 23: $1-5$.

Ternois Y, Sicre MA ANd PATerne M. 2000. Climatic changes along the northwestern African continental margin over the last 30 kyrs. Geophys Res Letts 27: 133-136.

Viana AR, Faugeres JC, Kowsmann RO, Lima JAM, CADDAH LFG AND RizzP JG. 1998. Hydrology, morphology and sedimentology of the Campos continental margin, offshore Brazil. Sedim Geol 115: 133-157.

ZEMBRUSCKI SG. 1979 Geomorfologia da margem continental sul brasileira e das bacias oceânicas adjacentes. In: Chaves HAF (Ed), Geomorfologia da margem continental brasileira e áreas oceânicas adjacentes (relatório final). PETROBRAS-DNPM-CPRM-DHN-CNPq, Rio de Janeiro, RJ, Brasil, p. 129-177. 